\title{
First record of the hexanchoid shark genus Crassodontidanus (Chondrichthyes: Hexanchiformes) from the Jurassic of Hungary \\ (Mecsek Mts, Southern Hungary), with a summary of the hexanchiform fossil record of Hungary
}

\author{
Márton SzABó ${ }^{1,2}$ \\ ${ }^{1}$ Department of Palaeontology, Eötvös Loránd University, \\ H-1117 Budapest, Pázmány Péter sétány 1/C, Hungary; \\ ${ }^{2}$ Department of Palaeontology and Geology, Hungarian Natural History Museum, \\ H-1083 Budapest, Ludovika tér 2, Hungary.E-mail: szabo.marton.pisces@gmail.com
}

\begin{abstract}
The first occurrence of Crassodontidanidae of Hungary is described. The material consists of a single tooth, currently placed in private collection. The specimen was found nearby Magyaregregy, at the so-called Síngödör outcrop, in the Middle Jurassic (Bathonian) Óbánya Limestone Formation. The tooth is characterized by a serrated mesial cutting edge of the main cusp, high root with convex mesial and distal margins. This character combination readily distinguishes the tooth from those of Hexanchidae. Currently, this is the oldest representation of Hexanchiformes in the fossil record of Hungary, which widens our knowledge on the distribution patterns of Crassodontidanidae. Summarized data of the hexanchiform fossil record of Hungary is also detailed here. The data show the presence of 3 families (Crassodontidanidae, Hexanchidae, Heptranchidae) with 5 genera (Crassodontidanus, Notidanodon, Hexanchus, Notorynchus and Heptranchias) from the Bathonian (Jurassic) to the Badenian (Miocene). With 22 figures and 1 table.
\end{abstract}

Key words - Bathonian, Crassodontidanidae, Crassodontidanus, Hexanchiformes, Magyaregregy

\section{INTRODUCTION}

Hexanchiformes is a monophyletic group of plesiomorphic squalomorph neoselachians, with a fossil record extending back into to the Jurassic (KRIWET $\&$ KLUG 2011). Their fossil record is dominated by isolated teeth; however, articulated skeletons are also known (KRIWET \& KLUG 2004, 2011, 2014). The order has 7 extant species, representing two suborders with three families (Chlamydoselachidae: Chlamydoselachus (2); Hexanchidae: Hexanchus (3), Notorynchus (1); Heptranchidae: Heptranchias (1) (Pollers Pöck \& ST RAUbe 2018).

Crassodontidanidae Kriwet et Klug 2016 was first described by KRIWET \& KLUG (2011), as Crassonotidae. The family is currently grouped into the suborder Hexanchoidei, together with Hexanchidae and Heptranchidae. Crassodontida- 
nidae is the most plesiomorphic family within the order Hexanchiformes, ranging from the Sinemurian (Early Jurassic) to the Hauterivian (Early Cretaceous) and including three genera: Crassodontidanus, Notidanoides and Pachybexanchus (KRIWET \& KLUG 2011). Crassonotidanids had their greatest taxonomic diversity in the Jurassic (KRIWET \& KLUG 2011).

The Mesozoic occurrence of Hexanchiformes in Hungary is sporadic. Up to now, Mesozoic hexanchiforms are known only from two localities of Hungary: the Valanginian Mogyorósdomb Limestone Formation nearby Hárskút (Hexanchidae indet.; Sza bó 2017), and the Kimmeridgian-Tithonian Pálihálás Limestone Formation nearby Olaszfalu (Notidanodon sp., Hexanchidae; Szabó in press).

The present study describes the oldest currently known hexanchoid hexanchiform fossil of Hungary, found in the Mecsek Mts (Southern Hungary), and summarizes the hexanchiform fossil record of the country.

\section{GEOLOGICAL SETTING}

The locality lies in the eastern part of the Mecsek Mts (Southern Hungary), south from the village of Magyaregregy (Figs 1, 2). The Síngödör is an east-west side valley, situated south from the Márévár Valley, in the main valley running from Magyaregregy to Zobákpuszta, also running down easterly from the hills bordering the Kisújbánya syncline (Figs 2, 3). Upper Jurassic then Bajocian beds are exposed in the western end of this valley. Along the folded sequence, outcrops become poorer toward the clayey marls of the Upper Bajocian. The Bathonian outcrop is rather poor, exposing only a few beds in a slightly domed structure. In the low cuts of the stream, this is followed by reddish calcareous marls and nodular limestones, represented by the typically red or variegated, nodular Óbánya Limestone Formation (GALÁCZ 1994, 2012) (Fig. 4). The hexanchiform tooth detailed in the present study was collected from this formation (L. Sövér, pers. comm.).

The Óbánya Limestone Formation is a $10-20 \mathrm{~m}$ thick formation, a so-called „ammonitico-rosso" facies, characteristic for the Tethyan Province (PRICE $e t$ al. 2018; CsÁszÁr et al. 2013). Kovács (1953, p. 91) gave a short list of ammonites unearthed here with the conclusion that the collected ammonites indicate a mainly Bathonian age for the limestone, while Early Callovian is also represented. Later on, GALÁcz $(1994,2012)$ re-visited the outcrops, and a usual ammonite faunula was collected. Galácz also re-investigated the collected specimens of Kovács, and concluded that (on the basis of all the hitherto known fossils) the investigated red nodular Middle Jurassic limestone of the Mecsek Mts represents the Bathonian only. 
Belemnites, brachiopods, and bivalves also occur in the formation. Based on the investigation of the microfaunal elements (foraminifers and ostracods), the sediment was deposited in an off-shore, medium to deep bathyal environment with relatively poor nutrient supply (CsÁszÁR et al. 2013). In the present days, the Síngödör outcrops are poor and overgrown, and although the characteristic rock is easy to identify, a bed-by-bed collecting cannot be carried out (GALÁCZ 1994).
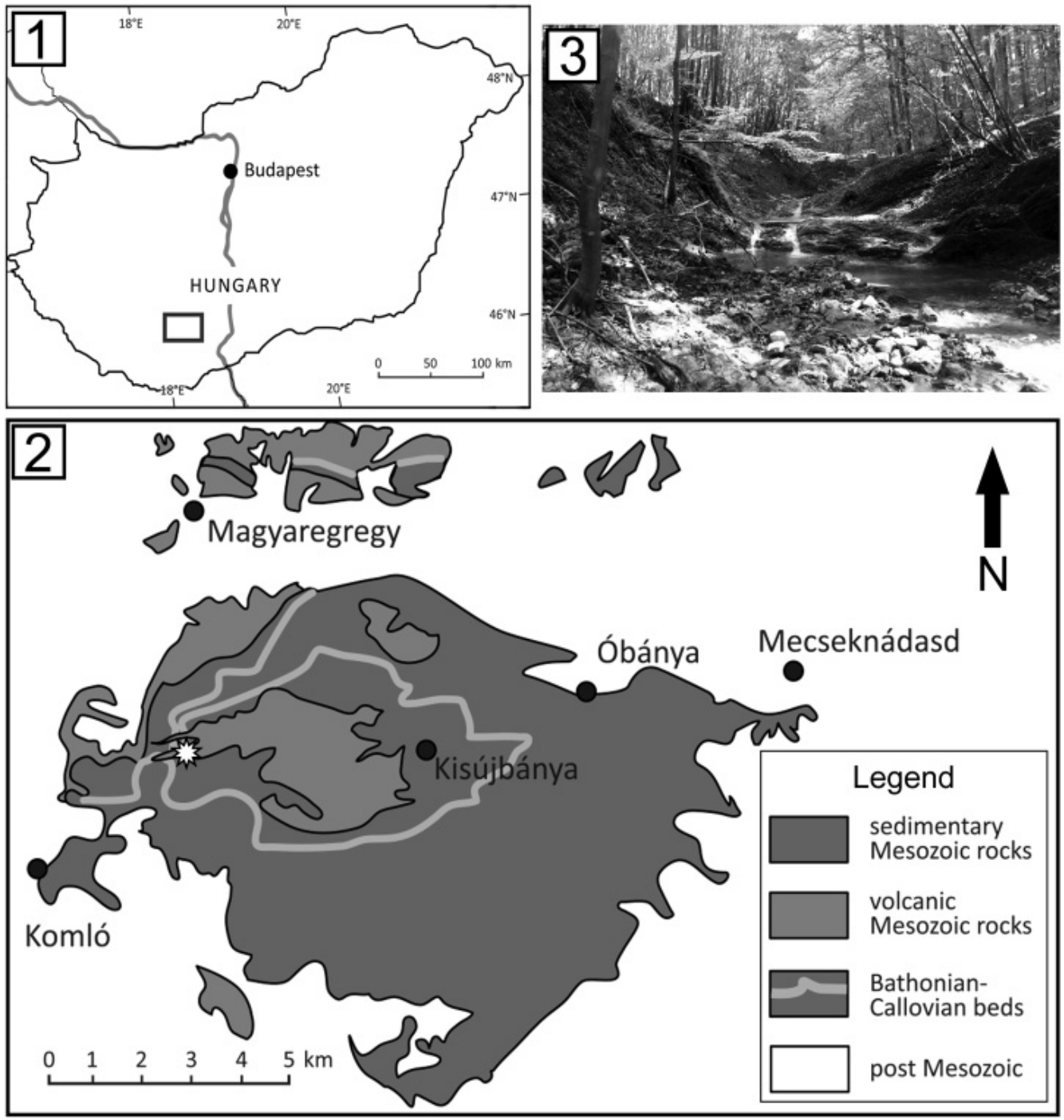

Fig. 1. Location map of the Óbánya Valley within Hungary (modified after PRICE et al. 2018). Fig. 2. Distribution of Mesozoic sedimentary and volcanic units within the Mecsek Mts (modified after PRICE et al. 2018 and GALÁcz 1994). - Fig. 3. The Síngödör site in 2016 (photo courtesy of Csaba Papp) 


\section{MATERIAL AND METHODS}

The Magyaregregy tooth specimen detailed in the present study is stored in the private collection of László Sövér (Bonyhád-Majos), who found the tooth on the 4th of July, in 1993. Seven replicas were made after the original tooth. Protesil Putty was used for making the negative, while the replicas themselves were made of Acrystal Prima acrylic resin. All replicas are housed in the vertebrate fossil collection of the Hungarian Natural History Museum, Budapest.

Tooth anatomical terminology for describing the Magyaregregy hexanchiform tooth follows the work of CAPpetTa (2012) and KRIWET \& KLUG (2011). For measuring tooth dimensions ImageJ software (version 1.48) was used.

For summarizing the hexanchiform fossil record an exhaustive search has been carried out both in literature, and in museum and private collections. Institutional abbreviations used in the text: $\mathrm{MGSH}=$ Mining and Geological

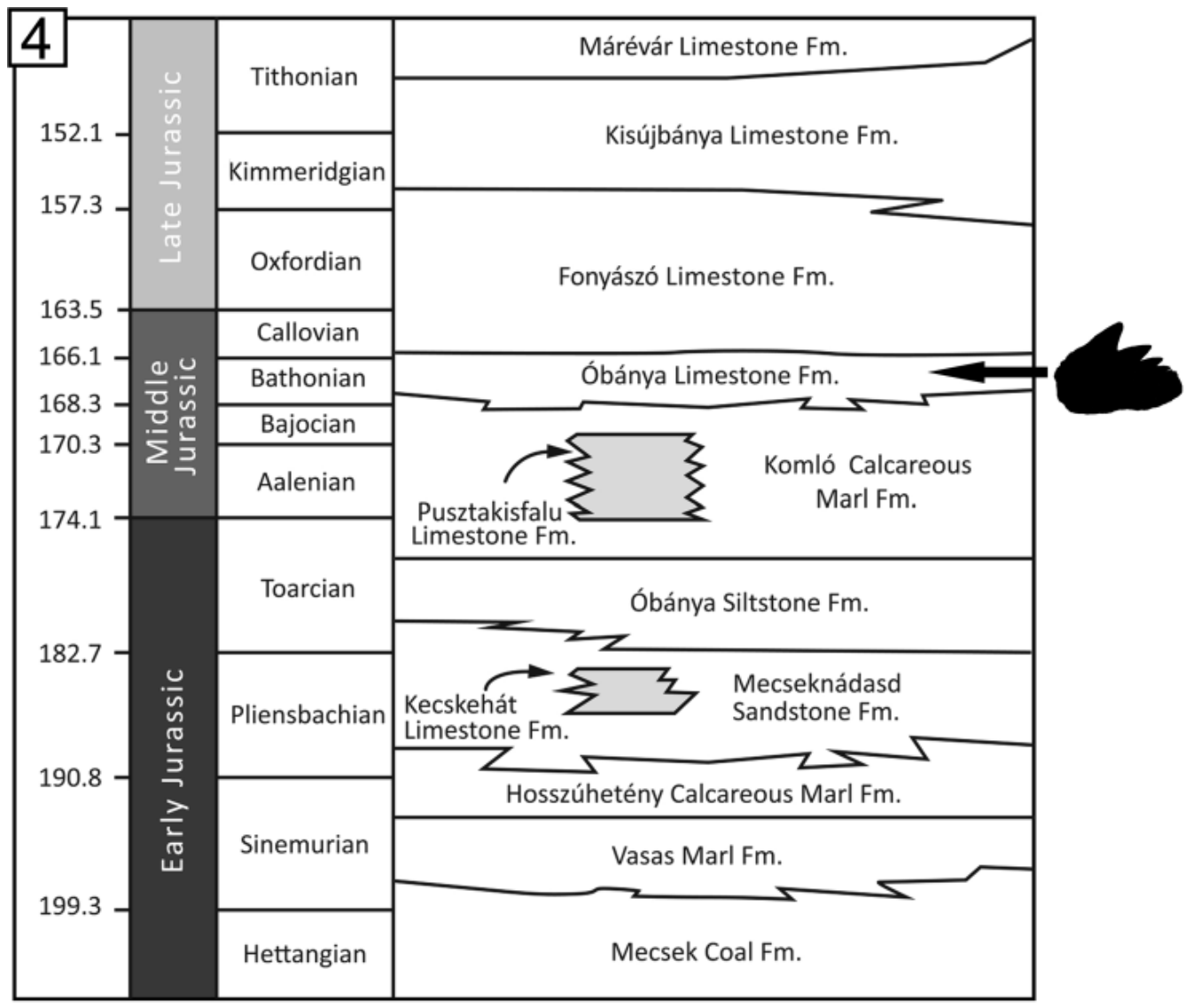

Fig. 4. Lithostratigraphical scheme for the Jurassic deposits of the Mecsek Zone (Southern Hungary) (modified after PRICE et al. 2018) and stratigraphical position of the studied tooth 
Survey of Hungary, NHMUS = Hungarian Natural History Museum, PTE $=$ University of Pécs. In some cases hexanchiform teeth are only mentioned in references, but referable tooth fossils stored in any museum (or private) collections of Hungary, are unknown.

\section{SYSTEMATIC PALAEONTOLOGY}

Superclass Chondrichthyes Huxley, 1880

Cohort Euselachii Hay, 1902

Subcohort Neoselachii Compagno, 1977

Order Hexanchiformes De Buen, 1926

Suborder Hexanchoidei Garman, 1913

Family Crassodontidanidae Kriwet et Klug, 2016

Genus Crassodontidanus Kriwet et Klug, 2011

\section{Crassodontidanus sp.}

(Figs 5, 6)

Referred material: 1 lower lateral tooth (stored in L. Sövér private collection); 7 replicas (NHMUS VER 2018.2310.1-7.).

Description - The tooth is $9.6 \mathrm{~mm}$ of mesiodistal length, and $6 \mathrm{~mm}$ of apicobasal height. It is still embedded in a piece of stone-matrix, in which it is displayed in lingual aspect. The mesial cutting edge of the main cusp is serrated, no well-marked mesial cusplets are present. The main cusp is distally inclined, massive and stout. The apical half of the mesial cutting edge is slightly convex, while the distal cutting edge of the main cusp is straight. Three distally inclined distal cusplets, decreasing gradually in size distally, are preserved. The neck of the tooth crown is well-developed, the root is high, possessing a convex outline. Remains of the lingual root bulge are visible; however, the lingual root face is poorly preserved. The basal root face is broad, the preserved root-portions refer to a slightly convex mesial and distal outline.

Taxonomic assignment - Following CAPPETTA (2012), the Magyaregregy hexanchiform lower tooth shows typical hexanchoid morphology by being strongly labiolingually flattened, and by being characterized by a crown with a main cusp followed by a series of distal cusplets (,accessory cusps" by CAPPETTA 2012) decreasing distally in size. Isolated tooth remains of hexanchoid families are mainly distinguishable by the dental characteristics of the lower teeth.

Hexanchidae and Heptranchidae expose dental characters different from those of the Magyaregregy specimen. Hexanchidae possess multicuspid lower teeth with rectangular root strongly compressed labiolingually with the basal root face being almost vertical (KRIWET \& KLUG 2011), conversely to the 


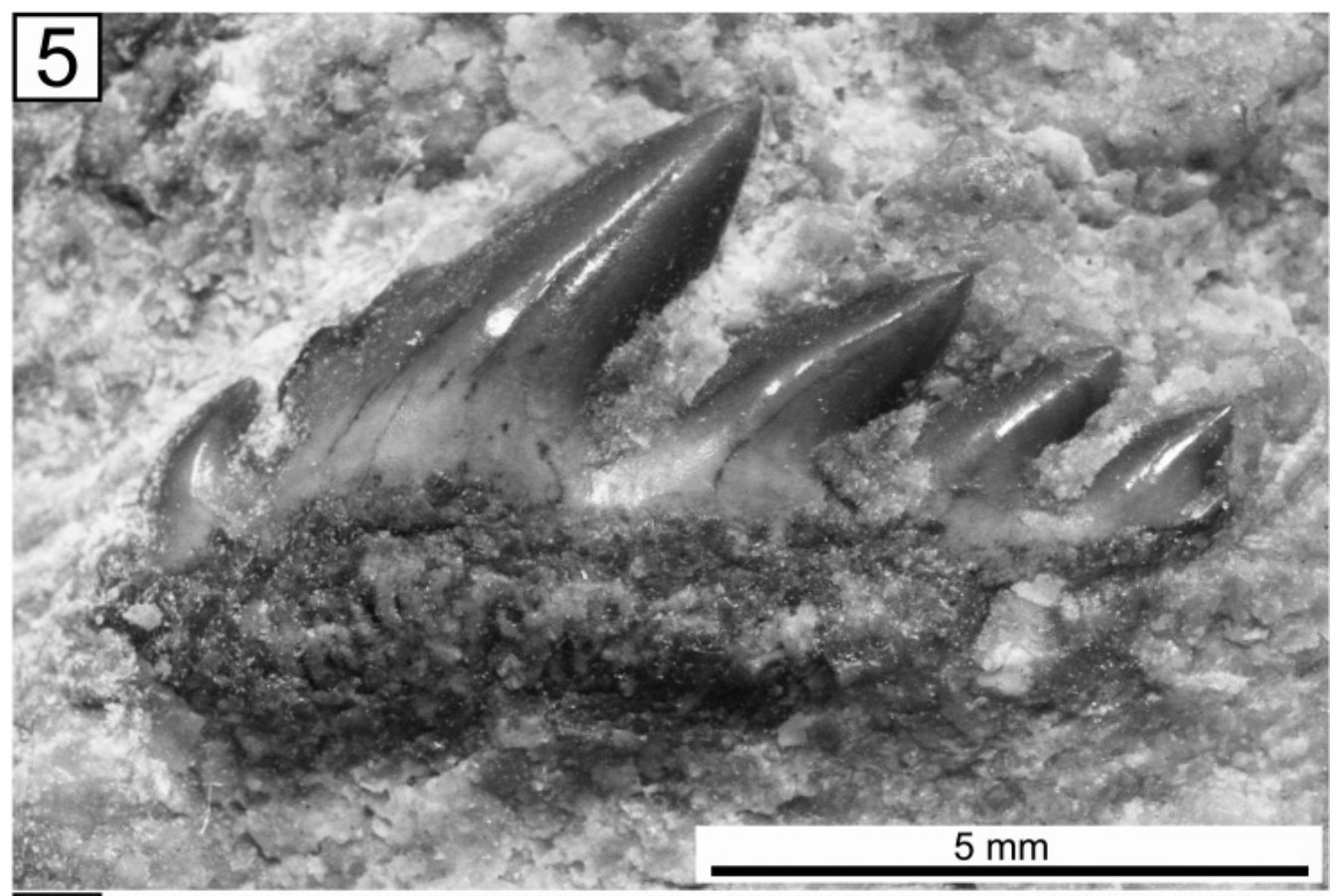

6

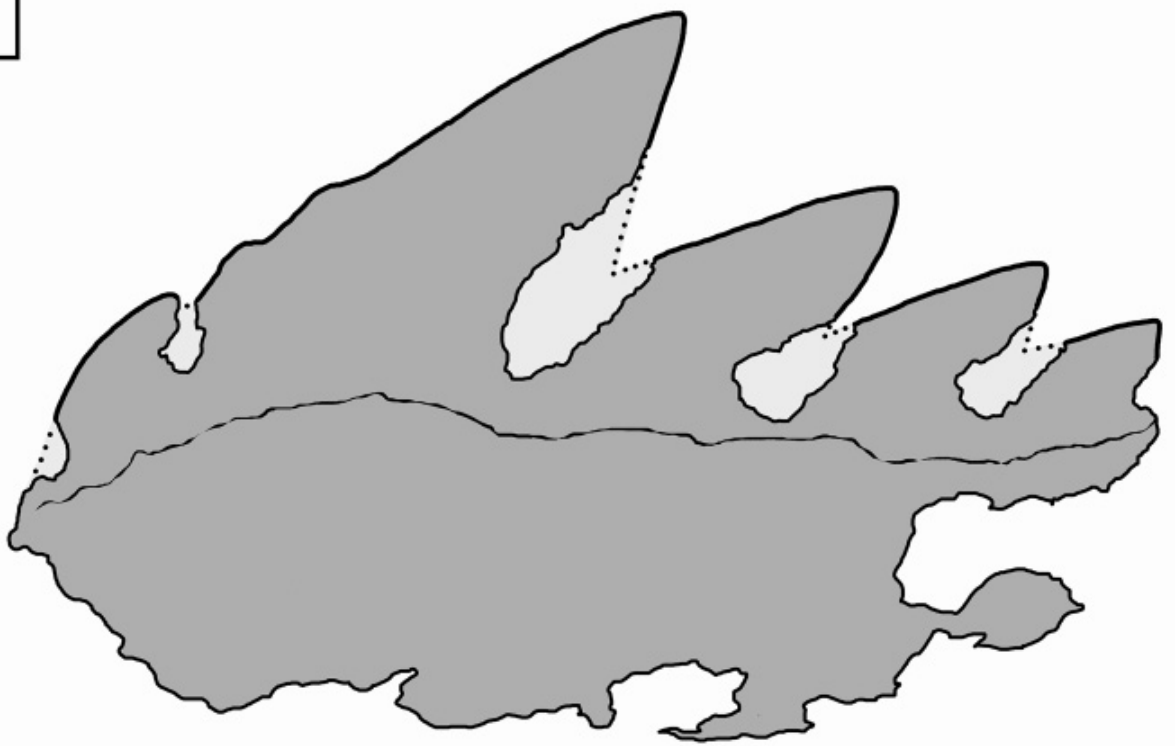

Fig. 5. Crassodontidanus sp. lower tooth from the Bathonian (Middle Jurassic) Óbánya Limestone Formation of the Síngödör (nearby Magyaregregy, Mecsek Mts, Southern Hungary), in lingual aspect. - Fig. 6. Line drawing of the same view 
Magyaregregy hexanchoid tooth. In Heptranchidae and some Hexanchidae, the mesial serrations form well marked mesial cusplets. An important character of lower heptranchid teeth is that the size of distal cusplets decreases irregularly to the distal edge of the tooth (CAPPETTA 2012). This differs in the Magyaregregy tooth, which bears distal cusplets regularly decreasing in size distally.

The third (and last) hexanchoid family Crassodontidanidae includes Crassodontidanus, Notidanoides, and Pachybexanchus. The generic description of the Magyaregregy tooth is challenging. KRIWET \& KLUG (2011) listed the following dental characters for the crassodontidanid Crassodontidanus: 1 - the upper and mesial teeth are multicuspid; 2 - only weak dignathic and monognathic heterodonties are present; 3 - the mesial cutting edge of main cusp is serrated; 4 - no mesial cusplets are present; 5 - the main cusp is stout and massive; 6-up to seven accessory cusplets, decreasing gradually in size distally are present; 7 - the crown neck is well-developed; 8 - the root is thick and high with convex outline in labial and lingual views; 9 - a prominent lingual root bulge is present; 10 - the basal root face is oblique in profile views forming an acute angle; 11 - the basal root face is broad and slightly convex. Among the listed characters, 3, 4, 5, 6, 7, 8, 9 , and 11 are visible on the Magyaregregy specimen.

Character 3 seems to be an important character, because serrated mesial cutting edge of the main cusp is present only in Crassodontidanus among all crassodontidanids (KRIWET \& KLUG 2011). This genus ranges from the Pliensbachain to the Kimmeridgian (KRIWET \& KLUG 2011), covering the Bathonian age of the Magyaregregy crassodontidanid.

To sum up, the preserved dental characteristics clearly assign the Magyaregregy tooth to Crassodontidanus, member of family Crassodontidanidae. Crassodontidanus currently includes two species, C. serratus and C. wiedenrothi, but since the Magyaregregy tooth is an isolated specimen, a specific assignment would not be established.

\section{DISTRIBUTIONAL PATTERNS OF CRASSODONTIDANIDAE}

The family ranges from the Sinemurian (Notidanoides muensteri, originally as Notidanus arzoensis from the Sinemurian of Switzerland; DE BEAUmonT 1960 ) to the Lower Cretaceous (Pachybexanchus pockrandti from the Hauterivian of Northern Germany; WARD \& Thies 1987). Geographically, the family shows a simple distributional pattern: only European reports are known. This includes Spain, France, England, Germany, Switzerland, Poland, Hungary, Crimea, and numerous localities in Western Russia (FURIC 2016; GUINOT et al. 2014; Kriwet \& Klug 2011, 2014 and references therein; Rees 2010; Trikolidi 2014; Fig. 7). Until the present study, the Carpathian Basin was a blind spot in 


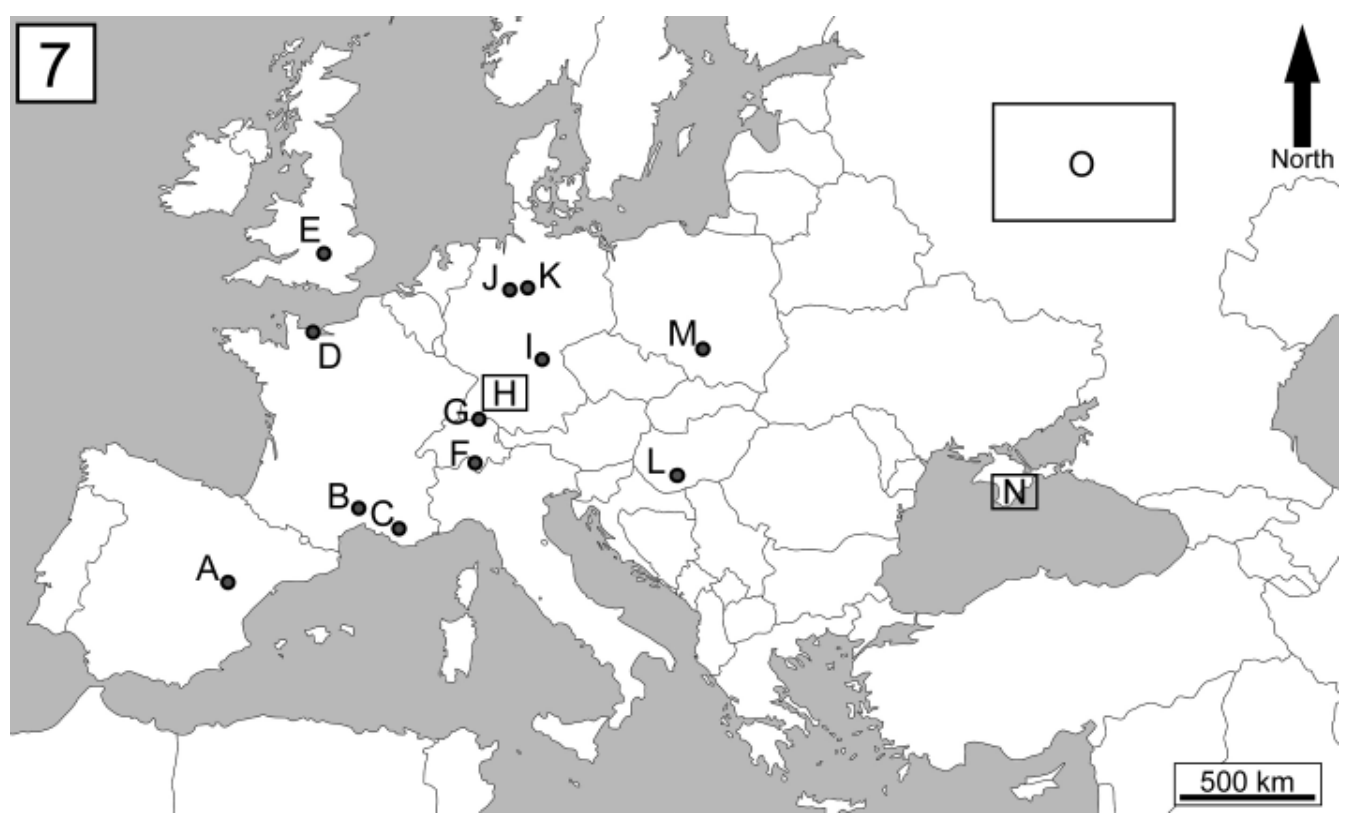

Fig. 7. Geographical distribution of Crassodontidanidae. - A = North-Eastern Spain, Moscardon (Upper Jurassic). - B = Southern France, La Cadière-et-Cambo (Lower Cretaceous). - C = Southern France, Rians (Upper Jurassic). - D = France, Normandy, Calvados (Middle to Upper Jurassic). - E = England, Oxford (Upper Jurassic). - F = Switzerland, Canton Ticino (Lower Jurassic). - G = Switzerland, Canton Schaffhausen (Upper Jurassic). - H = Fossil sites of Southern Germany (Baden-Württemberg: Gingen an der Fils, Glems, Lauchleim, Mahlstetten, Nusplingen, Schnaitheim, Lochen, Stuifen [all Upper Jurassic]; Bavaria: Daiting, Eichstätt, Solnhofen [all Upper Jurassic]). - I = Southern Germany, Franconian Alb, Streitberg (Late Jurassic). - J = Northern Germany, Engelbostel (Lower Cretaceous). $-\mathrm{K}=$ Northern Germany, Gretenberg near Hanover (Lower Jurassic). - L = Southern Hungary, Mecsek Mts, Magyaregregy (Middle Jurassic). $-\mathrm{M}=$ Southern Poland, Orgodzieniec (Middle to Upper Jurassic). - N = Fossil sites of Crimea (Bolshoy Kermen Mountain [Lower Cretaceous] and Belaya Mountain [Upper Cretaceous]). $-\mathrm{O}=$ Russia, several localities in the Moscow Basin (Lopatinsky Phosphorite Mine, Egorievsk Mine, basin of the Nara River, banks of the Moskva River at Mnevniki Village, Dyad'kovo, Kolomna, Tyrnovo, Mikhalenino [all Upper Jurassic]). - After FURIC 2016; GUINot et al. 2014; KRIWET \& KLUG 2011, 2014 and references therein; ReEs 2010; TRIKOLIDI 2014. Some Russian occurrences are based on yet unpublished teeth, photography available at http://naturephoto.ru/Fossils/s-9038.htm. The map does not show questionable or unsure reports (e.g. "?Notidanoides sp." in UNDERWOOD \& WARD 2004)

the crassodontidanid record of Europe, most likely by the undersampled Jurassic marine sediments, in looking after chondrichthyan remains.

\section{THE HEXANCHIFORM FOSSIL RECORD OF HUNGARY}

Order Hexanchiformes is represented in the vertebrate fossil record of Hungary by suborder Hexanchoidei with 3 families: Crassodontidanidae, Hexanchidae, and 
Heptranchidae (see Table 1). Apart from detailed and/or illustrated reports of various hexanchiform taxa occurring in the fossil record of Hungary, a few incomplete or new reports are detailed below. For museum or private collection specimens available for a non-illustrated or new reports, see Figs 8-22.

Eocene - A lower hexanchiform tooth, housed in the private collection of Mihály Dunai, was found at an Eocene outcrop nerby Lábatlan (Gerecse Mts, Northern Hungary) (Figs 8, 9). The tooth is still embedded in a piece of stonematrix, in which it lies in lingual aspect. The tooth has a distally inclined main cusp, followed by 8 distal cusplets, gradually decreasing in size. The root has a rectangular outline with a broad and straight basal margin. The mesial cutting edge is still covered by sediment. Based on the preserved and visible dental characters, this tooth is attributed to Hexanchus.

One upper hexanchiform tooth, unearthed from the Middle Eocene of Oroszlány-Szépvízér (Vértes Mts, North-Western Hungary), is housed in the vertebrate fossil collection of the MGSH (Figs 10, 11). It has one slightly sigmoid, slender main cusp, flanked by two mesial and one distal cusplets. The root is rectangular in labial and lingual views, reaching its maximal thickness just below the crown base. The general tooth characteristics refer the tooth to Hexanchus.

The Upper Eocene (Priabonian) Szépvölgy Limestone Formation of the Lapos Quarry (Üröm, Buda Hills) yielded a fragmentary hexanchiform tooth (NHMUS VER 2018.2304.; Fig. 12). The tooth was found by Tamás Németh, and it is currently stored in the vertebrate fossil collection of the NHMUS. The main cusp and the preserved first distal cusplet (similar to the main cusp but apicobasally lower) are more upright than teeth of Hexanchidae, the well-marked mesial cusplets ( 4 in number) distally increasing in size. The section of the mesial cusplets is arched. The crown neck is horizontal, almost the whole root is missing. The preserved characters refer the tooth with close relation to Heptranchias, which is widely distributed in the Eocene.

The Szépvölgy Limestone Formation is exposed in the Martinovits Quarry (Kissvábhegy, Budapest) as well. One lower tooth of Heptranchias howelli, placed in the private collection of Adam Anderson, is known from here (Fig. 13). The tooth is embedded in a piece of limestone, in lingual aspect. The size of distal cusplets decreases irregularly distally (with the last 1-2 distal cusplets suddenly decreasing in height). The root is flat, low and rectangular.

Miocene - Vast majority of the hexanchiform record of Hungary comes from the Miocene. The Middle Miocene (Badenian) fossil site of Nyirád exposes two fossiliferous formations for fossil vertebrates: the Kolontár Member of the Pusztamiske Formation, and the Pécsszabolcs Member of the Leitha Limestone Formation (Szabó \& Kocsis 2016a). Notorynchus primigenius is known from the Pusztamiske Formation since 2016, but recently a fragmentary lower tooth 


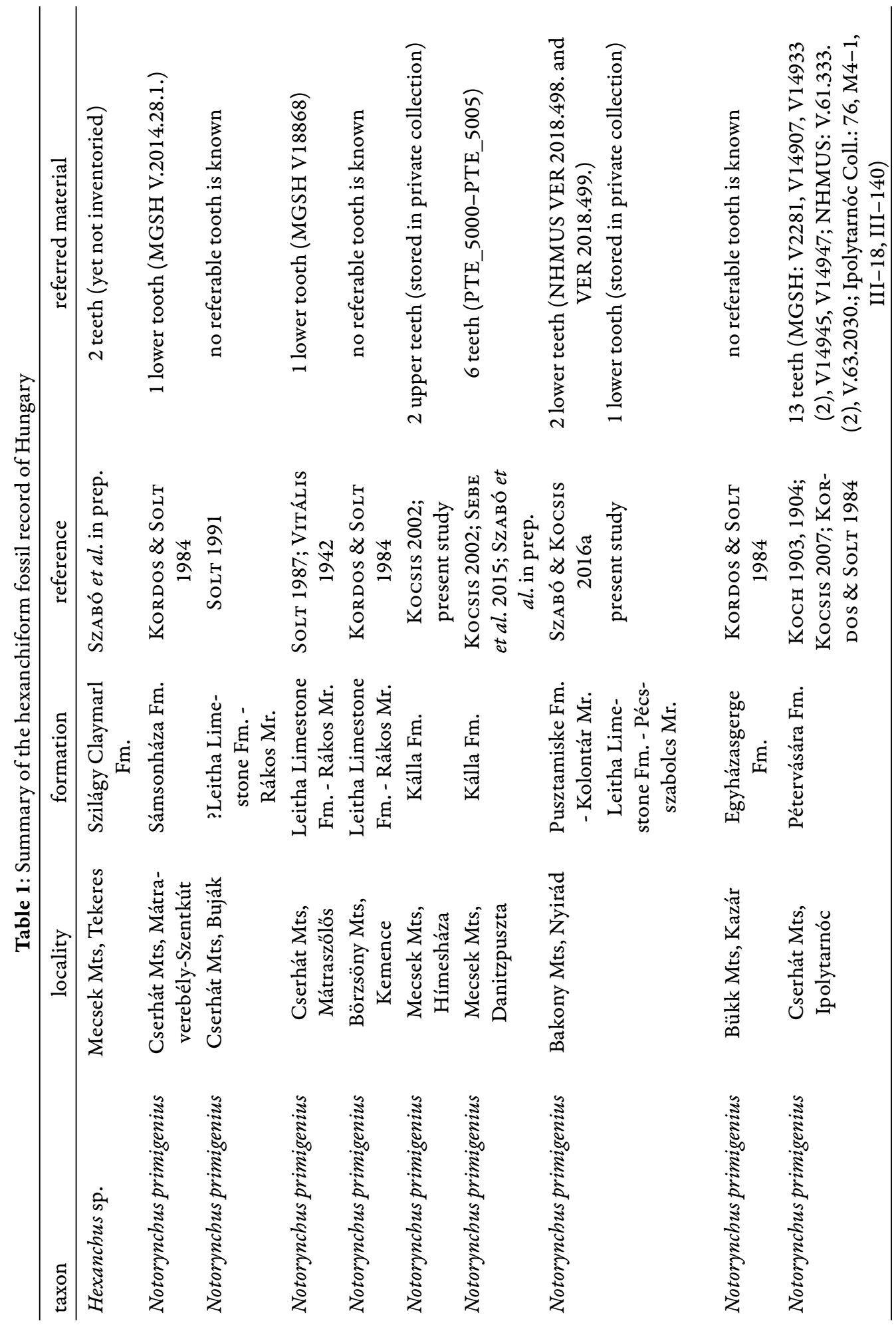




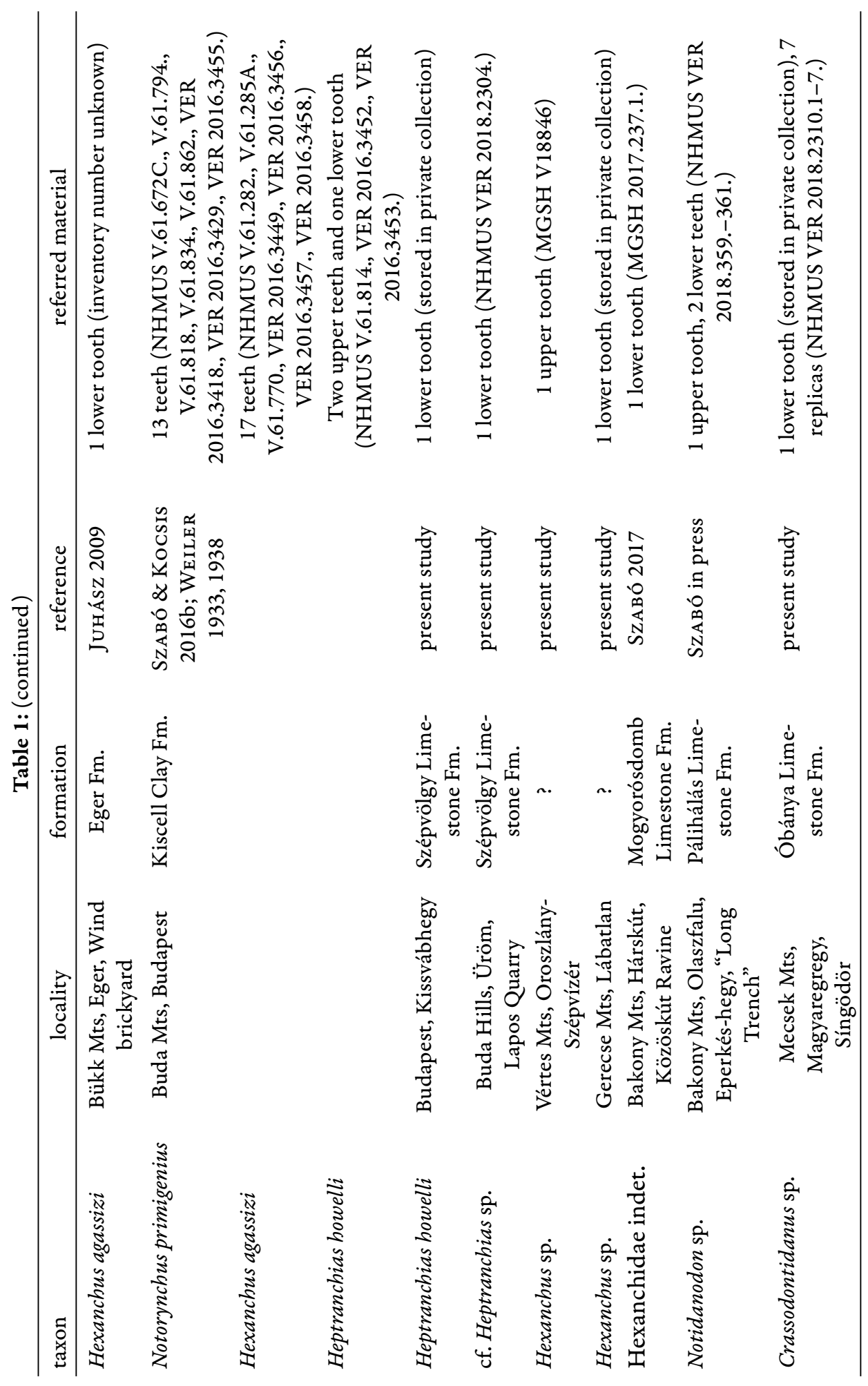



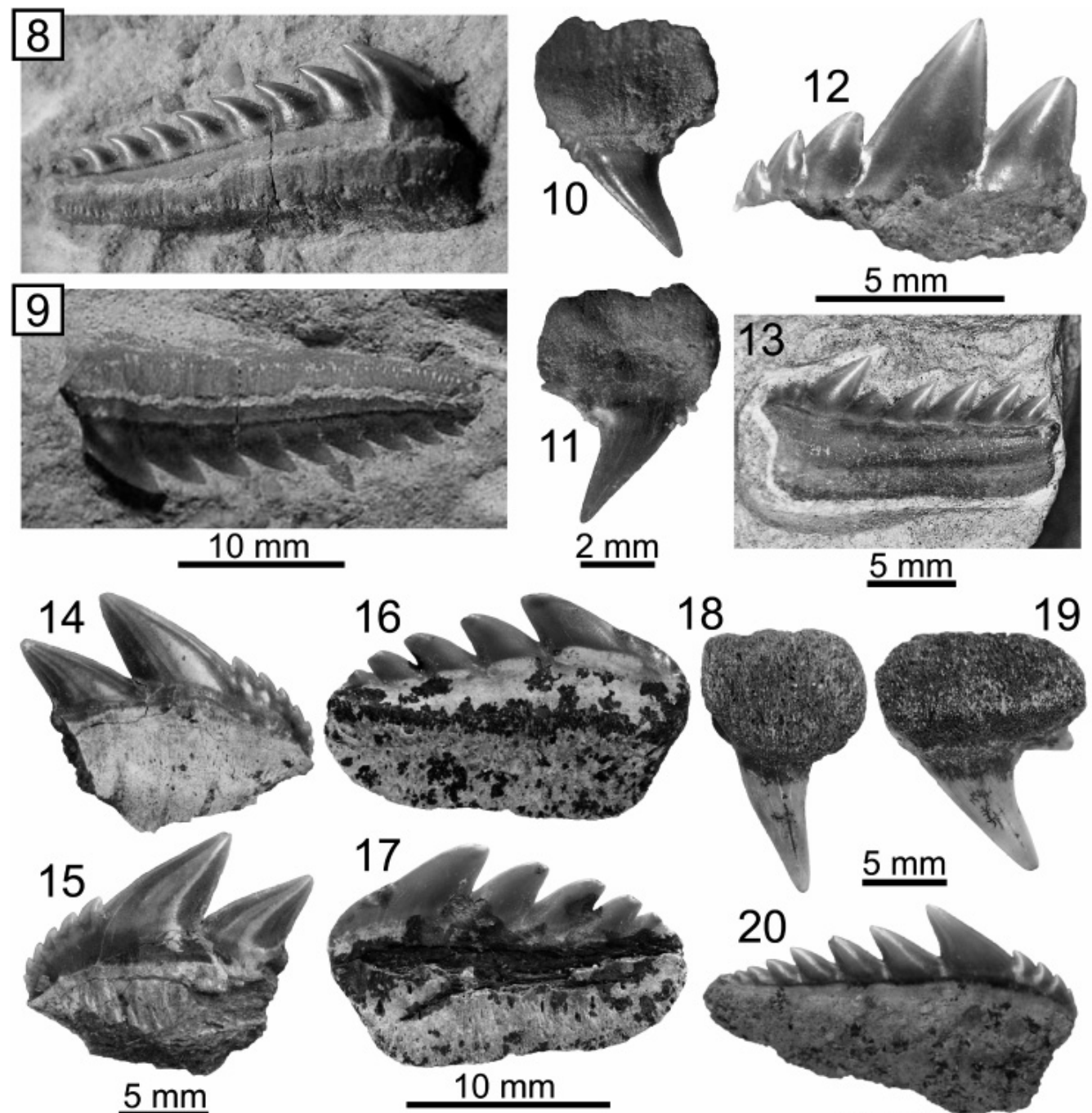

18

19

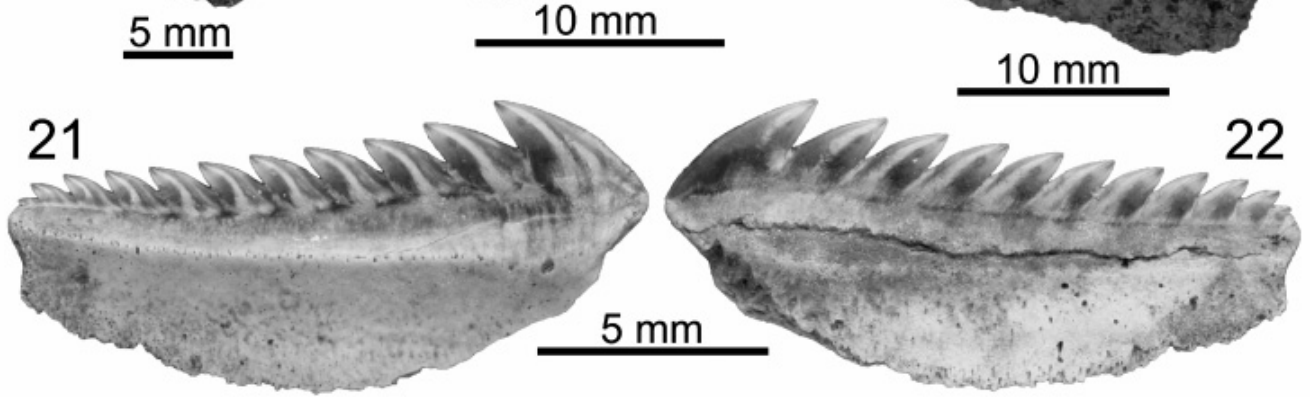

Figs 8-9. Hexanchus sp. lower tooth from the Eocene of Lábatlan, from the private collection of Mihály Dunai (lingual aspect, in two different views). - Figs 10-11. Hexanchus sp. upper tooth (MGSH V18846) from the Middle Eocene of Oroszlány-Szépvízér. - Fig. 10. Lingual view. - Fig. 11. Labial view. - Fig. 12. Heptranchias sp. fragmentary lower tooth (NHMUS VER 2018.2304.) from the Upper Eocene (Priabonian) Szépvölgy Limestone Formation of the Lapos Quarry (Üröm, Buda Hills), in lingual view. - Fig. 13. Heptranchias howelli lower tooth from the Upper Eocene 
of $N$. primigenius, found in the Pécsszabolcs Member of the Leitha Limestone Formation has been re-discovered in a private collection (Figs 14, 15).

The Middle Miocene (Badenian) Kálla Formation, exposed in the Danitzpuszta sand pit (Mecsek Mts, Southern Hungary) is a well-known fossil site for chondrichthyans and osteichthyans. Up to now, only one, poorly preserved lower tooth of Notorynchus primigenius, came from the Danitz-puszta sand pit has been figured in a Field Trip Guidebook (SEBE et al. 2015, p. 116, fig. 4.6J). In 2017, the University of Pécs recieved a large private collection of Danitz-puszta fish remains, with a few well-preserved teeth of $N$. primigenius (SzABó et al. in prep.). Among them, one lower tooth is figured on Figs 16, 17.

The same formation is exposed at Hímesháza, from where $N$. primigenius is also known (Figs 18, 19). This occurrence was reported, but not figured by Kocsis (2002). Two teeth are referred here, both are placed in private collection of László Sövér, exposing the typical characteristics of the upper teeth of $N$. primigenius: the teeth are mesiodistally shorter than apicobasally high, the main cusp is enlarged and distally inclined, the distal cusplets are small and few in number (they might lack anteriomost files), the root (convex labially, while flat lingually) is labiolingually flattened and rectangular in outline (it reaches its maximal thickness just below the crown base).

Notorynchus primigenius has been reported, but not figured from various Miocene localities of Hungary by Kordos \& Solt (1984). Among them, one tooth of $N$. primigenius from the Middle Miocene (Badenian) Sámsonháza Formation of Mátraverebély-Szentkút (Cserhát Mts, Northern Hungary) is housed in the vertebrate fossil collection of the MGSH (Fig. 20). The tooth bears typical characteristics of the lower teeth of $N$. primigenius.

The Szilágy Claymarl Formation (also Badenian in age) near Orfü-Tekeres (Mecsek Mts, Southern Hungary) also yielded hexanchiform teeth of excellent condition (Figs 21, 22). Two lower teeth are referred here, with finely serrated

(Priabonian) Szépvölgy Limestone Formation of the Martinovits Quarry (Kissvábhegy, Budapest), from the private collection of Adam Anderson (in lingual view). - Figs 14-15. Notorynchus primigenius fragmentary lower tooth from the Middle Miocene (Badenian) Leitha Limestone Formation of Nyirád (from the private collection of László Bécsi). - Fig. 14. Lingual view. - Fig. 15. Labial view. - Figs 16-17. Notorynchus primigenius lower tooth (PTE 5004) from the Middle Miocene (Badenian) Kálla Formation of the Danitz-puszta sand pit. - Fig. 16. Lingual view. - Fig. 17. Labial view. - Figs 18-19. Notorynchus primigenius upper teeth from the Middle Miocene (Badenian) Kálla Formation of Hímesháza, from the private collection of László Sövér. - Fig. 18. Upper anterior tooth in lingual view. - Fig. 19. Upper antero-lateral tooth in lingual view. - Fig. 20. Notorynchus primigenius lower tooth (MGSH V.2014.28.1.) from the Middle Miocene (Badenian) Sámsonháza Formation of Mátraverebély-Szentkút, in lingual view. - Figs 21-22. Hexanchus sp. lower tooth (yet uninventoried specimen) from the Middle Miocene (Badenian) Szilágy Claymarl Formation of Orfü-Tekeres. - Fig. 21. Lingual view. - Fig. 22. Labial view 
mesial cutting edge, followed by a main cusp and numerous distal cusplets gradually decreasing in size distally, and with flattened root, rectangular in labial and lingual views. According to these characters, the teeth represent Hexanchus, most likely $H$. agassizi, however, further specimens are needed for a specific assignment (SzABó et al. in prep.).

\section{CONCLUSION}

The Magyaregregy Crassodontidanus tooth is of great importance, since it is the first occurrence of the family Crassodontidanidae in Hungary, and also in the whole Carpathian Basin. It provides new data to the geographic and stratigraphic distributional patterns of the genus Crassodontidanus. The Magyaregregy Crassodontidanus sheds light on the importance of the taxonomical elaboration of the Mesozoic fish material of the Mecsek Mts, and also the whole country.

Hexanchoidei is represented in the Hungarian fossil record by all of its three families: Crassodontidanidae (Bathonian), Hexanchidae (Kimmeridgian-Tithonian - Badenian) and Heptranchidae (Priabonian - Kiscellian [Rupelian]). Up to now, fossils of the hexanchiform suborder Chlamydoselachoidei are unknown from the fossil record of Hungary. Since our current knowledge on the Mesozoic Hexanchiformes of Hungary is still rather poor, the revision of further material, deposited in museum and private collections, is required.

Acknowledgements - The author is grateful to Jürgen Pollerspöck, whose constructive comments highly improved an earlier version of the manuscript. Many thanks go to László Sövér (Bonyhád-Majos), who allowed the author to investigate his private collection. The author is grateful to Tamás Bertalan (Bonyhád), who helped in the making of replicas, and to contact with private collectors. Adam Anderson, László Bécsi, Mihály Dunai, and Tamás Németh are acknowledged for their cooperation with their private collection specimens. A special thank goes to Csaba Papp, for his photography of the Síngödör. The author is highly thankful to István Fözy for providing many useful literatures on the geology of the Mecsek Mts. Krisztina Sebe (University of Pécs) is acknowledged for allowing me to study the hexanchiform shark teeth, deposited in the collection of the University of Pécs. This study was funded by the National Research, Development and Innovation Office (OTKA K1 16665 and PD104937), the Hungarian Natural History Museum, the Eötvös Loránd University, and the ELTE Dinosaur Research Group.

\section{REFERENCES}

Beaumont G. De 1960: Contribution à l'étude des genres Orthacodus Woodward et Notidanus Cuv. (Selachii). - Schweizerische Paläontologische Abhandlungen 77: 4-36.

Cappetta H. 2012: Handbook of Paleoichthyology, Vol. 3E: Chondrichthyes. Mesozoic and Cenozoic Elasmobranchii: Teeth. - Verlag Dr. Friedrich Pfeil, Munich, 512 pp. 
CsászÁr G., Szinger B. \& Piros O. 2013: From continental platform towards rifting of the Tisza Unit in the Late Triassic to Early Cretaceous. - Geologica Carpathica 64(4): 279-290. https://doi.org/10.2478/geoca-2013-0020

FURIC M. 2016: Les chondrichthyens de la série callovo-oxfordienne (Jurassique moyen-supérieur) de Normandie. - Unpublished Master's thesis, Université de Rennes 1, 23 pp.

Galácz A. 1994: Ammonite stratigraphy of the Bathonian red, nodular marl in the Mecsek Mts, south Hungary. - Annales Universitatis Scientiarum Budapestinensis de Rolando Eötvös Nominatae, Sectio Geologica 30: 115-150.

GALÁcz A. 2012: Néhai Kovács Lajos professzor Mecsek hegységi középső-jura ammoniteszei. (The Middle Jurassic ammonites of the Mecsek Mts (South Hungary) in the collection of the late Professor Lajos Kovács). - Földtani Közlöny 142(4): 313-320. (in Hungarian with English abstract)

Guinot G., Cappetta H. \& Adnet S. 2014: A rare elasmobranch assemblage from the Valanginian (Lower Cretaceous) of southern France. - Cretaceous Research 48: 54-84. https://doi.org/10.1016/j.cretres.2013.11.014

Juhász T. 2009: Porcoshal maradványok az Eszterházy Károly Főiskola Földrajz Tanszékének Gyüjteményében. [Chondrichthyan remains from the collection of the Eszterházy Károly University.] - In: PÁlfy J., Bosnakoff M. \& Vörös A. (eds): Program, Elöadáskivonatok, Kirándulásvezetö, 12. Magyar Öslénytani Vándorgyülés, 2009. május 28-30, Sopron, p. 22. (in Hungarian)

Kосн A. 1903: Tarnócz Nógrád megyében, mint kövült czápafogaknak új gazdag lelőhelye. [Tarnócz in Nógrád County, a new and rich locality for fossil shark teeth.] - Földtani Közlöny 33: 22-44. (in Hungarian)

Косн A. 1904: Pótlék a tarnóczi alsómediterrán homokkő czápafaunájához: Notidanus diffusidens n. fr. [Supplement to the lower Mediterranean shark fauna of Tarnócz: Notidanus diffusidens n. fr.] - Földtani Közlöny 34: 202-203. (in Hungarian)

Kocsis L. 2002: Mecsek környéki porcoshal maradványok. [Miocene Chondrichthyes remains from the area of the Mecsek Mountains.] - In: Program, Elöadáskivonatok, Kirándulásvezetö, 5. Magyar Öslénytani Vándorgyülés, 2002. május 3-4, Pásztó, p. 20. (in Hungarian)

Kocsis L. 2007: Central Paratethyan shark fauna (Ipolytarnóc, Hungary). - Geologica Carpathica 58(1): $27-40$.

Kordos L. \& SolT P. 1984: A magyarországi miocén tengeri gerinces faunaszintek vázlata. (An outline of Hungary's Miocene marine vertebrate faunal horizons.) - A Magyar Állami Földtani Intézet Évi Jelentése 1982-röl: 347-354. (in Hungarian with English abstract)

KovÁcs L. 1953: A Mecsekhegység felső-dogger rétegei. (Les couches du Dogger Supérieur de la Montagne Mecsek.) - A Magyar Állami Földtani Intézet Évi Jelentése az 1950-es évröl: 89-95. (in Hungarian with French and Russian abstracts)

KRIWET J. \& KlUG S. 2004: Late Jurassic selachians (Chondrichthyes, Elasmobranchii) from southern Germany: Re-evaluation on taxonomy and diversity. - Zitteliana A44: 67-95.

KRIWET J. \& KLUG S. 2011: A new Jurassic cow shark (Chondrichthyes, Hexanchiformes) with comments on Jurassic hexanchiform systematics. - Swiss Journal of Geosciences 104(1): 107-114. https://doi.org/10.1007/s00015-011-0075-z

KRIWET J. \& Klug S. 2014: Dental patterns of the stem-group hexanchid shark, Notidanoides muensteri (Elasmobranchii, Hexanchiformes). - Journal of Vertebrate Paleontology 34(6): 1292-1306. https://doi.org/10.1080/02724634.2014.874353

PollerspöCK J. \& STRAUBE N. 2018: Bibliography database of living/fossil sharks, rays and chimaeras (Chondrichthyes: Elasmobranchii, Holocephali). www.shark-references.com, World Wide Web electronic publication, Version 2018 [accessed 01-12-2018] 
Price G. D., Fözy I. \& Galácz A. 2018: Carbon cycle history through the Middle Jurassic (Aalenian-Bathonian) of the Mecsek Mountains, Southern Hungary. - Geologica Carpathica 69(2): 117-127. https://doi.org/10.1515/geoca-2018-0007

ReEs J. 2010: Neoselachian sharks from the Callovian-Oxfordian (Jurassic) of the Ogrodzieniec, Zawiercie Region, Southern Poland. - Palaeontology 53(4): 887-902.

https://doi.org/10.1111/j.1475-4983.2010.00967.x

Sebe K., Csillag G., Dulai A., Gasparik M., Magyar I., Selmeczi I., Szabó M., Sztanó O. \& Szuromi-Korecz A. 2015: Neogene stratigraphy in the Mecsek Region. - 6th Workshop on the Neogene of Central and South-Eastern Europe. Hungarian Geological Society. In: An RCMNS Interim Colloquium. Programme, Abstracts, Field Trip Guidebook, 31 May-3 June 2015, Orfü, Hungary, pp. 102-124.

Solt P. 1987: Legányi Ferenc nyomában Mátraszőlősön a Procarcharodonok lelőhelyén. (In track of Ferenc Legányi at the locality of Procarcharodon in Mátraszőlős.) - Folia Historico-Naturalia Musei Matraensis 12: 15-18. (in Hungarian with English abstract)

Solt P. 1991: Tengeri halmaradványok a Hasznos környéki felső-miocénből. (Marine fish remains from the Upper Miocene in the vicinity of Hasznos). - A Magyar Állami Földtani Intézet Évi Jelentése 1989-röl: 473-479. (in Hungarian with English abstract)

Szabó M. 2017: Fish remains from the Lower Cretaceous (Valanginian-Hauterivian) of Hárskút (Hungary, Bakony Mts). - Fragmenta Palaeontologica Hungarica 34: 49-61. https://doi.org/10.17111/FragmPalHung.2017.34.49

Szabó M. in press: A Late Jurassic (Kimmeridgian - early Tithonian) fish fauna of the Eperkéshegy (Olaszfalu, Bakony Mts, Hungary): the oldest record of Notidanodon Cappetta, 1975 and a short revision of Mesozoic Hexanchidae. - Palaeobiodiversity and Palaeoenvironments

Szabó M. \& Kocsis L. 2016a: A new Middle Miocene selachian assemblage (Chondrichthyes, Elasmobranchii) from the Central Paratethys (Nyirád, Hungary): implications for temporal turnover and biogeography. - Geologica Carpathica 67(6): 573-594. https://doi.org/10.1515/geoca-2016-0036

Szabó M. \& Kocsis L. 2016b: A preliminary report on the Early Oligocene (Rupelian, Kiscellian) selachians from the Kiscell Formation (Buda Mts, Hungary), with the re-discovery of Wilhelm Weiler's shark teeth. - Fragmenta Palaeontologica Hungarica 33: 31-64. https://doi.org/10.17111/FragmPalHung.2016.33.31

SzABó M., Kocsis L. \& SEBE K. in prep.: Chondrichthyan and osteichthyan remains from the Badenian (Middle Miocene) Szilágy Clay Marl Formation (Tekeres, Mecsek Mts, Southern Hungary).

TRI KOLIDi F. A. 2014: Cow sharks (Hexanchiformes) from the Cretaceous deposits of the Crimea. - Proceedings of the Zoological Institute, Russian Academy of Sciences 318(1): 76-97. (in Russian with English abstract)

UNDERWOOD C. J. \& WARD D. J. 2004: Environmental distribution of Bathonian (Middle Jurassic) neoselachians in southern England. - In: Mesozoic Fishes 3 - Systematics, Palaeoenvironments and Biodiversity. - Verlag Dr. Friedrich Pfeil, München, pp. 111-122.

VITÁLIs I. 1942: A recens notidanusok és a fosszilis Notidanus primigenius Ag. fogazata, fö tekintettel a mátraszöllősi miocénkorú Notidanus-fogakra. (Die Zähne der rezenten Notidanus-Arten und des fossilen Notidanus primigenius Ag., mit besonderer Rücksicht auf die miozänen NotidanusZähne von Mátraszöllős.) - Geologica Hungarica, Series Palaeontologica 18: 1-38.

Ward D. J. \& Thies D. 1987: Hexanchid shark teeth (Neoselachii, Vertebrata) from the Lower Cretaceous of Germany and England. - Mesozoic Research 1(2): 89-106.

WeILER W. 1933: Zwei oligozäne Fischfaunen aus dem Königreich Ungarn. - Geologica Hungarica, Series Palaeontologica 11: 1-54, 3 pl.

WeILER W. 1938: Neue Untersuchungen an mitteloligozänen Fischen Ungarns. - Geologica Hungarica, Series Palaeontologica 15: 1-31, $6 \mathrm{pl}$. 